\title{
Specific binding of proteins from Rhizobium meliloti cell-free extracts containing NodD to DNA sequences upstream of inducible nodulation genes
}

\author{
Robert F. Fisher, Thomas T. Egelhoff, John T. Mulligan, and Sharon R. Long1 \\ Department of Biological Sciences, Stanford University, Stanford, California 94305-5020 USA
}

\begin{abstract}
Nodulation (nod) genes in Rhizobium meliloti are transcriptionally induced by flavonoid signal molecules, such as luteolin, produced by its symbiotic host plant, alfalfa. This induction depends on expression of nodD. Upstream of three inducible nod gene clusters, nodABC, nodFE, and nodH, is a highly conserved sequence referred to as a 'nod box.' The upstream sequences have no other obvious similarity. We have found that DNA fragments containing the regions upstream of all three inducible transcripts show altered electrophoretic mobility when treated with $R$. meliloti extracts. The ability of the extracts to interact specifically with these DNAs correlated with the genetic dosage of nodD1 or nodD3 and with the presence and concentration of the nodD1 or nodD3 protein (NodD1 or NodD3) in the extracts. Antiserum specific to NodD was used to construct an immunoaffinity column that permitted a substantial purification of NodD1; this preparation of NodD1 also displayed specific binding to restriction fragments containing DNA sequences found upstream of inducible nod genes. In addition, NodD-specific antiserum removed the specific DNA-binding activity from total Rhizobium cell extracts. The interaction of total extracts and of partially purified NodD protein with nod promoter sequences was competitive with an oligonucleotide representing the 3 ' 25 -bp portion of the nod box. The interaction of $R$. meliloti extracts and NodD1 protein with nod gene upstream regions occurred independently of exposure of cells or extracts to flavone inducer.
\end{abstract}

[Key Words: nod gene; nodD; promoter; transcription; flavone induction; Rhizobium]

Received September 24, 1987; revised version accepted January 25, 1988.

Infection of legume roots by appropriate Rhizobium bacteria leads to the establishment of a nitrogen-fixing symbiosis. Both bacterial and host plant genes are involved in the formation of root nodules that harbor the nitrogen-fixing bacteroids. Several sets of bacterial genes involved in the formation of root nodules (nod genes) have now been identified by mutation and DNA sequence analysis (reviewed by Long 1986). One set, genes nod $A B C$, appears to be required for deformation of epidermal root hairs, formation of the infection thread, and nodule morphogenesis in several Rhizobium and $\mathrm{Bra}$ dyrhizobium species (for DNA sequence definitions of nod $A B C$, see Rossen et al. 1984; Egelhoff et al. 1985; Jacobs et al. 1985; Schofield and Watson 1986; Scott 1986, Törok et al. 1984). Other genes required for efficient nodulation include nodFEGH in $R$. meliloti (Debelle and Sharma 1986; Horvath et al. 1986; Fisher et al. $1987 \mathrm{~b}$ ) and nodFE in Rhizobium leguminosarum biovar. viciae and trifolii (Schofield and Watson 1986; Shearman et al. 1986). Transposon and deletion-complementation studies in several species suggest that additional genes

${ }^{1}$ Corresponding author. for nodulation also exist (see Debelle et al. 1986; Djordevic et al. 1985a; Evans and Downie 1986; Putnoky and Kondorosi 1986).

The nodABC, nodFE, and nodH genes of $R$. meliloti 1021 are not expressed in free-living cells; however, in the presence of the host plant or plant exudates, these genes can be induced over 30-fold, as shown by a nod $C^{\prime}-$ 'lacZ translational fusion (Mulligan and Long 1985), immunological assay of nodA protein (Egelhoff and Long 1985), and assay of transcript abundance of nodFE, nodH, and nodABC by primer extension (Fisher et al. $1987 \mathrm{~b}$; J. Mulligan and S. Long, in prep.). We have shown previously that induction of nodABC requires the expression of the R. meliloti nodD-gene product (Mulligan and Long 1985). Similarly, we have recently found that induction of $R$. meliloti nodF and nodH also requires nodD (J. Swanson and S. Long, unpubl.). Rossen et al. (1985) and Shearman et al. (1986) have also shown that induction of $R$. leguminosarum biovar. viciae nodABC and nodF require expression of the nodD-gene product. We have identified the most active inducing compound in alfalfa seed exudate as luteolin $\left(3^{\prime}, 4^{\prime}, 5,7\right.$-tetrahydroxy flavone) (Peters et al. 1986). Induction of nod-lac 
gene or operon fusions by plant flavonoids has also been shown in $R$. leguminosarum biovar. viciae (Rossen et al. 1985; Zaat et al. 1987) and trifolii (Innes et al. 1985).

Three other flavones, not including luteolin, were identified as the most active inducers in clover root exudates (Redmond et al. 1986). Synthetic flavonoids tested on R. leguminosarum biovar. viciae (Firmin et al. 1986; Zaat et al. 1987) show that the most active flavonoid inducers for different Rhizobium species have different structures. This difference and ability to respond to different legumes can vary according to the species source of the nodD gene (Horvath et al. 1987; Spaink et al. 1987). Complementation studies in these systems have shown that nodD can be the limiting factor in Rhizobium host selectivity (Horvath et al. 1987; Spaink et al. 1987), although in other cases, it functions without affecting host range (Djordevic et al. 1985b; Fisher et al. 1985). Mutations in nodD can alter the requirement for and response of nodD protein and inducing compounds (Burn et al. 1987). Mutations in nodD are $\mathrm{Nod}^{-}$in $R$. leguminosarum biovar. viciae and trifolii but are $\mathrm{Nod}^{+}$ in $R$. meliloti. R. leguminosarum biovar. viciae and trifolii each have a single copy of nodD, but $R$. meliloti harbors three nodD homologs. Each of the three homologous genes will allow some nodulation in the absence of the other two (Göttfert et al. 1986; Honma and Ausubel 1987). nodD adjacent to nod $A B C$ in $R$. meliloti is now referred to as nodD1, and the other two loci are referred to as nodD2 and nodD3. Strains that lack all three nodD homologs are Nod- (Honma and Ausubel 1987).

The deduced sequence of the nodD-gene product is highly conserved in different Rhizobium species (Egelhoff et al. 1985; Göttfert et al. 1986; Schofield and Watson 1986; Scott 1986; Shearman et al. 1986), and a region of the amino-terminal end of the sequence resembles the proposed DNA-binding domain of the products of the Escherichia coli araC and lys $R$ genes (Shearman et al. 1986; Appelbaum et al. 1985). Like nodD, those $E$. coli genes positively regulate the expression of an adjacent, divergently transcribed operon. In addition, both araC and lys $R$ are autoregulatory, a behavior that has also been observed with $R$. leguminosarum biovar. viciae nodD (Rossen et al. 1985).

Starting 26-28 bp upstream of the primer extensiondefined transcription initiation sites of $\operatorname{nod} A, \operatorname{nod} F$, and nodH (Fisher et al. 1987b; J. Mulligan and S. Long, in prep.) lies an extensively conserved segment of DNA (Debelle and Sharma 1986; Rostas et al. 1986; Schofield and Watson 1986; Scott 1986; Shearman et al. 1986; Fisher et al. 1987a,b; Spaink et al. 1987). This 'nod box' has been postulated to be involved in the coordinate regulation of the discrete sets of nod genes (Rostas et al. 1986). The mechanism by which this coordinate regulation is achieved can be described by a model proposing that the nod box serves as a recognition sequence for the binding of some activating factor(s), which directs transcription initiation by RNA polymerase (Shearman et al. 1986). In light of the requirement of nodD expression in activation of these sets of genes, the simplest model stipulates that the nodD-gene product fulfills the role as the activating factor and mediates the effect of the flavonoid inducer.

In the present study, we test some of the predictions of this model. We demonstrate that extracts from Rhizobium strains that overproduce either the cloned nodD1or nodD3-gene products cause a marked reduction in the electrophoretic mobility of restriction fragments containing the nod boxes that lie upstream of nodA, nodF, and $\operatorname{nod} H$. The same behavior is displayed by a preparation of substantially purified nodD1. Three control restriction fragments lacking nod boxes are unaffected by these extracts or by the preparation of NodD1, suggesting that the nod box is required for the interaction to occur. Furthermore, involvement of the nod box was shown by the observation that a purified oligonucleotide duplex representing the 3 '-terminal half $(25 \mathrm{bp})$ of the nod box specifically competed with promoter DNA fragments for interaction with NodD-containing protein extracts. Using antibodies directed against nodD-gene products to deplete nodD protein from cellular extracts, we found that the extracts now lack the ability to retard the electrophoretic mobility of nod box-containing restriction fragments. These results suggest a direct interaction of nodD protein and/or tightly associated factors with the DNA upstream of inducible nod genes.

\section{Results}

Antibody to nodD protein recognizes all three R. meliloti nodD-gene products

Analysis of the role of the nodD-gene product (NodD) in activation of the inducible nod genes will be greatly facilitated by methods that permit detection of the nodDgene product(s). NodD is not expressed at conveniently high protein levels in $E$. coli, even using an exogenous promoter (Egelhoff and Long 1985). One reason for this might be that the mRNA 5' to the nodD translational start site has a poor resemblance to the consensus ribosome-binding site (Shine and Dalgarno 1974). We therefore constructed a hybrid gene in which the E. coli lacZ ribosome-binding site and first six codons are fused in frame to codon 7 of the $R$. meliloti nodD1 coding sequence. The resulting construct gave very high expression of a protein that formed inclusion bodies in E. coli host strain SVS3202 (Egelhoff 1987). These were collected and the $1 a c Z^{\prime}-$ 'nodD protein was purified by preparative electrophoresis, after which it was used to generate antiserum in a rabbit.

Because one of the complications of nodD analysis in $R$. meliloti is the presence of three homologous copies of nodD with at least partial function /Göttfert et al. 1986; Honma and Ausubel 1987; J. Mulligan and S. Long, in prep.), it was necessary to determine whether the antiserum generated against the nodD fusion protein interacted with more than one of the nodD-gene products. Each of the three NodD species was detected on Western blots of genetically engineered $R$. meliloti strains. The protein products of nodD1, nodD2, and nodD3 were expressed from clones to enhance their level, which made 


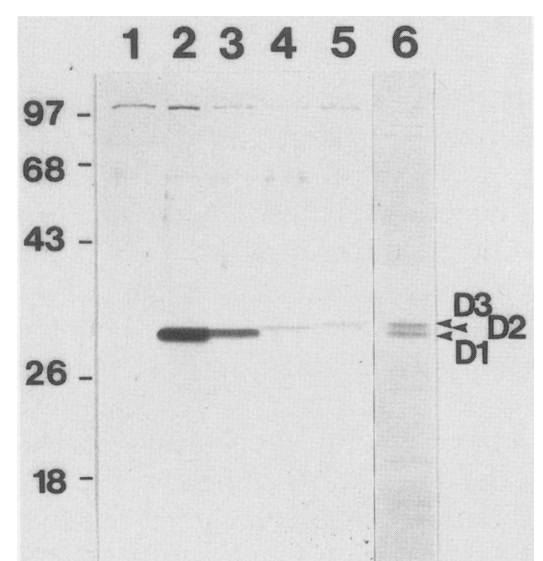

Figure 1. Reaction of nodD antiserum with proteins from various $R$. meliloti strain constructs. Following electrophoresis, protein extracts were subjected to Western blot analysis using antiserum to a lacZ'-'nodD hybrid protein, as described previously (Egelhoff and Long 1985). (Lane 1) R. meliloti 1400, a deletion of pSym with no copies of nodD genes. (Lane 2) $R$. meliloti 1021 (pRmE43), which overexpresses nodD1. (Lane 3) R. meliloti JM97 (pRmJ30), which contains a vector-borne copy of nodD1 controlled by its own promoter and is mutated for nodD2 and nodD3. (Lane 4) R. meliloti JM80 (pRmM137), which contains an extra copy of nodD2 on a vector and is mutated for nodD1 and nodD3. (Lane 5) R. meliloti JM98 (pRmM108), which contains an extra vector-borne copy of nodD3 and is mutated for nodD1 and nodD2. (Lane 6) R. meliloti 1021 (pRmJT5), which contains a normal pSym-borne nodD1 gene and an extra copy of nodD3 on a vector.

it possible to show that the antiserum recognizes each of the proteins and that they are distinguishable by apparent molecular size (Fig. 1). The difference in intensity of antibody labeling with the different nodD proteins may reflect either different affinity for the three homologs or differences in amounts of NodD in the extracts; we have no data at present to distinguish between these alternatives. $R$. meliloti strain 1400 is deleted for all three copies of nodD and gives no signal on the Western blot in the molecular weight range of NodD (Fig. 1, lane 1). R. meliloti strain 1021 (pRmE43) expresses nodD1 from an expression vector and gives a strong signal on Western blots at the predicted molecular weight for NodD (Egelhoff and Long 1985) (Fig. 1, lane 2). R. meliloti strain JM97 (pRmJ30) contains a vector-borne copy of nodD1 controlled by its own promoter and is mutated in nodD2 and nodD3. This strain also gives a strong signal on Western blots (Fig. 1, lane 3 ), although not as strong as strains containing the expression vector clone pRmE43. Strain JM80 (pRmM137) contains a vector-borne copy of nodD2 and is mutated in nodD1 and nodD3. On Western blots, this NodD2 strain gives a clear signal migrating at a slightly higher molecular weight than Nod1 (Fig. 1, lane 4). This correlates well with the slightly larger predicted molecular size of nodD2 based on its DNA sequence (Göttfert et al. 1986). Strain JM98 (pRmM108) contains an extra copy of
nodD3 on a plasmid and is mutated in nodD1 and nodD2. This strain also gives a clear signal on Western blots, migrating slightly less rapidly than the NodD1 or NodD2 signal (Fig. 1, lane 5). Strain 1021 (pRmJT5) contains a normal pSym-borne nodD1 gene and an extra copy of nodD3 on a vector. The Western blot of this strain further illustrates the difference in mobility of the NodD1 and NodD3 proteins (Fig. 1, lane 6); it also illustrates the amount of NodD1 expressed from a genomic copy of the nodD1 gene. Under our standard reaction conditions, a strain bearing only the native $\mathrm{pSym}$ copies of the nodD genes yields an extract in which only NodD1 protein is detectable following the Western blot protocol used here.

\section{Crude extracts from strains that overproduce NodD retard the electrophoretic migration of restriction fragments containing nod boxes}

To test the model of nodD-mediated activation of the inducible nod genes, we prepared extracts from various R. meliloti strains, which either did or did not overproduce the cloned nodD1- or nodD3-gene products. These extracts were then used to determine whether they contained a protein factor that could specifically bind to radiolabeled DNA restriction fragments from the region immediately upstream of the transcription initiation sites of these inducible genes (see Fig. 2). To assay DNA binding, we monitored the retardation of electrophoretic migration of restriction fragments that contained or lacked nod boxes (Fried and Crothers 1981; Miller et al. 1987).

We found that when three different restriction fragments containing the upstream regulatory regions of the inducible $\operatorname{nod} A$, nodF, and $\operatorname{nod} H$ genes (Fig. 2) were mixed with extracts from $R$. meliloti strains with insertional mutations in all three nodD genes, no apparent retardation of migration was observed compared with the control (Fig. 3, panels A,B,C, lanes 1 and 2). However, if extracts were used in which either nodD1 or nodD3 was overproduced on a plasmid, a substantial amount of fragment retardation occurred (Fig. 3, panels $A, B, C$, lanes 3 and 4). Protein-DNA interaction, as indicated by gel fragment retardation, was not displayed by three different restriction fragments that lacked nod boxes. One example is shown in Figure 3, panel $D$; the restriction fragment used contains sequences wholly internal to nodD1 (Egelhoff et al. 1985). Its electrophoretic migration is unaffected by mixing with extracts from cells that overproduce NodD. Interestingly, we have only observed electrophoretic retardation when the extracts were from a strain that overproduced NodD. Extracts from strains producing wild-type levels of NodD failed to retard nod-box fragments (data not shown). This corresponds to our observation of low in vivo nodgene induction in genotypes with wild-type copy number of nodD compared to higher induction in genotypes with high nodD copy number (Mulligan and Long 1985). 


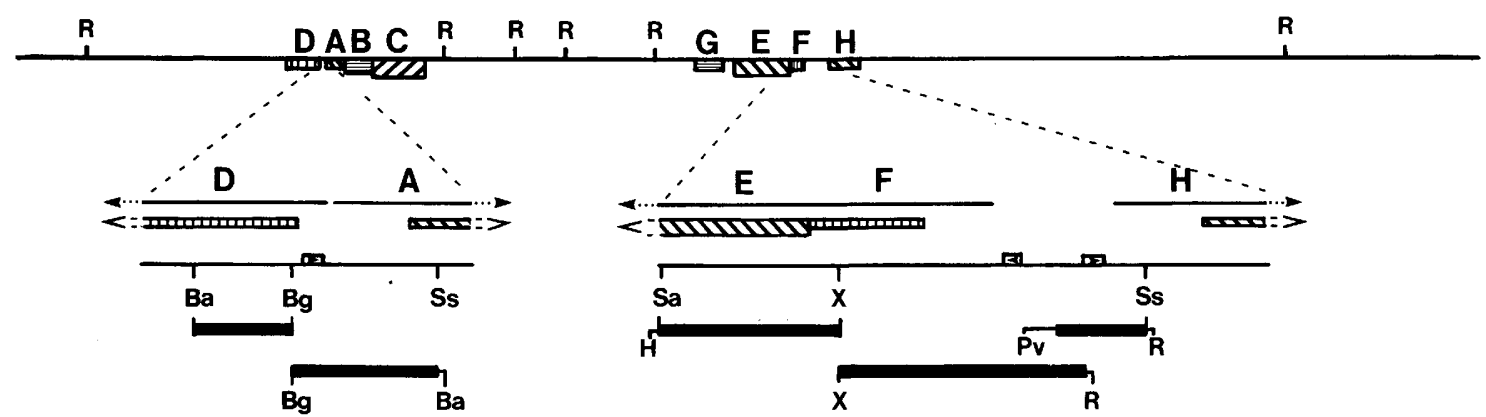

Figure 2. Map of $R$. meliloti 1021 (SU47 $\mathrm{Str}^{\mathrm{R}}$ ) nod-gene region. (Top) Map of nod genes (hatched boxes show open reading frames) located on pSyma. (Middle) Expanded scale showing position of transcripts (lines with arrowheads) and open reading frames (hatched boxes with arrowheads), and restriction map of cloned segments used to generate small fragments. Boxes with arrows indicate position of nod boxes. (Bottom) Small cloned segments used for gel retardation. Thick lines indicate R. meliloti DNA; thin lines represent vector polylinker DNA present in some digested fragments referred to in Figs. 3 and 4. (R) EcoRI; (Ss) SstI; (Pv) PvuII; (Xm) XmaI; (H) HindIII; (Sa) SalI; (Bg) BglII; (Ba) BamHI.

\section{Correlation of restriction fragment retardation with NodD}

The genetic dosage of nodD correlated with the ability of a strain to yield an extract that interacted with DNA sequences upstream of inducible nod genes, as determined by gel fragment retardation. However, because nodD is a regulatory gene, its presence and level of expression in a cell will have multiple effects besides the level of NodD itself. Therefore, we pursued two biochemical tests for a NodD-DNA interaction.

In the first test, competent extracts /which could cause electrophoretic retardation) were treated with either preimmune serum or anti-NodD serum coupled to protein A-Sepharose. Treatment of competent $R$. meliloti 1021 (pRmE43) extracts with preimmune serum prior to mixing with labeled restriction fragments had no effect on the specific formation of electrophoretically retarded complexes. Western blot analysis of extracts treated with preimmune serum showed no detectable change in the amount of NodD present in the extracts (data not shown). In contrast, treatment of the same extract with anti-NodD serum resulted in the loss of ability to form specifically retarded complexes. As determined by Western blot analysis, treatment with antiNodD serum significantly depleted NodD from the extracts (data not shown).

In a second approach, we used the anti-NodD serum to construct an immunoaffinity column and carried out a substantial purification of NodD1. Only two proteins that bound to the anti-NodD column were recovered after elution (Fig. 4, lane 1). One of these was NodD1, as shown by its size $(35 \mathrm{kD})$, its absence in nodD1 :: Tn5 strains, and its high reactivity on Western blots (Fig. 4, lane 3). Use of this affinity column thus results in a highly purified preparation of NodD1. The only contam-

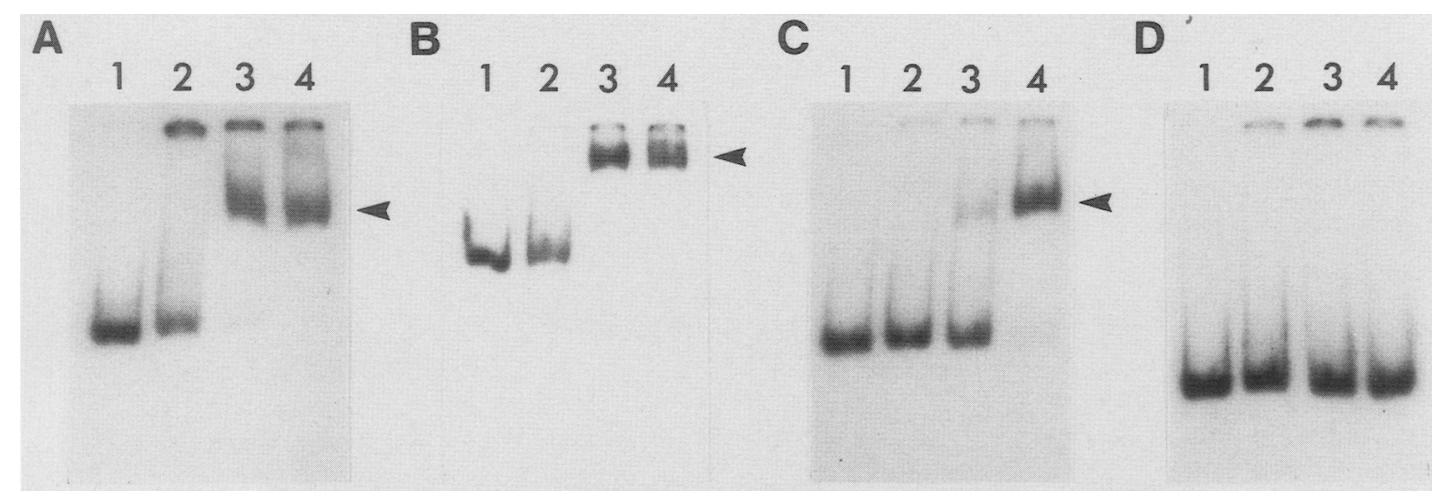

Figure 3. Ability to retard the migration of nod box-containing restriction fragments by $R$. meliloti cell-free extracts is dependent on NodD. (A) The 0.36-kb ${ }^{32} \mathrm{P}-$-labeled BglII-BamHI restriction fragment from pRmE36, which contains the segment upstream of nodA, including the nod box (see Fig. 2), was mixed under the conditions of the standard gel retardation assay, as described in Materials and methods, with $32 \mu$ g of crude extracts from: lane 2, R. meliloti strain JM90 (pTE3), which is mutated for all three nodD genes; lane 3, R. meliloti strain 1021 (pRmE43), which overproduces nodD1; lane 4, R. meliloti strain JM96 (pRmE65), which is mutated for nodD1 and nodD2 and overproduces NodD3. Lane 1 displays the electrophoretic migration pattern of labeled restriction fragment in the absence of any added crude extract. The arrowhead designates the electrophoretically retarded complex. $(B)$ Same as in $A$, except that the ${ }^{32}$ P-labeled DNA used was the 0.6-kb pRmRF58 EcoRI-XmaIII restriction fragment, which contains the nodF upstream DNA, including the nod box (Fig. 2). (C) Same as in $A$, except that the ${ }^{32} \mathrm{P}-$ labeled DNA used was the 0.35-kb EcoRI-PvuII restriction fragment from pRmRF59, which contains the nodH nod box (Fig. 2). (D) Same as in $A$, except that the ${ }^{32}$ P-labeled DNA used was the 0.24-kb BglII-BamHI restriction fragment from pRmE36, which contains sequences wholly internal to nodD1 (Fig. 2). 


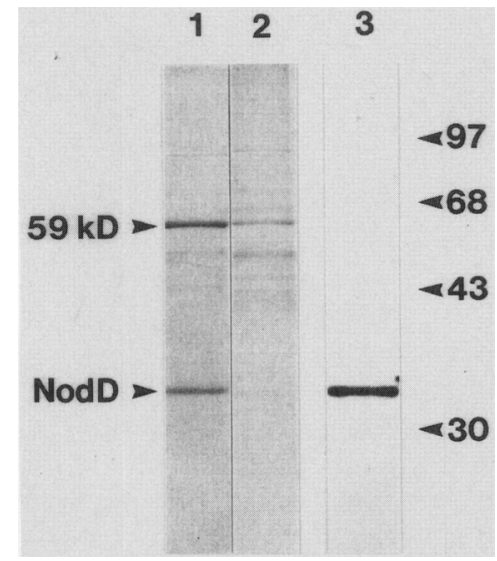

Figure 4. Substantial purification of NodDl by immunoaffinity chromatography. $R$. meliloti extacts were passed over a column bearing antiserum to the lac $Z^{\prime}-{ }^{\prime}$ nodD1 translational fusion protein. Proteins eluted by high $\mathrm{pH}$ treatment were visualized by polyacrylamide gel electrophoresis and Coomassie blue staining (lanes 1 and 2) or Western blot analysis (lane 3). (Lanes 1 and 3) R. meliloti strain 1021 (pRmE43) yields two proteins, one of which is the $35-\mathrm{kD}$ NodD1. The other, a $59-\mathrm{kD}$ protein, is visible by Coomassie staining but is not reactive with anti-NodD antibodies under Western blot conditions (lane 3). (Lane 2) $R$. meliloti strain JM90 (pTE3) is mutated for nodD1, nodD2, and nodD 3 and bears the cloning vector, pTE3, used to construct pRmE43. Immunoaffinity chromatography of extracts from this strain yields only the $59-\mathrm{kD}$ protein; no NodD proteins were detected on Western blots (data not shown). This fraction shows no interaction with nod promoters by gel retardation analysis, as shown in Fig. 5. Migration of protein standards are indicated in kilodaltons on the right. inating polypeptide in this NodDl preparation that was visible by Coomassie blue staining of samples run on SDS-polyacrylamide gels was a $59-\mathrm{kD}$ protein, which is apparently unrelated to NodD. This protein is present in strains with insertional mutations in all three nodD genes (JM90) and was found to bind to a freshly prepared anti-NodD column that had not been exposed to any NodD protein (Fig. 4, lane 2). Thus, it appears to interact with the column itself and not with NodD bound to the column. The protein does not interact with the Sepharose column matrix (data not shown) and is not detectable on Western blots probed with anti-NodD antibodies (see Figs. 1 and 4, lane 3). It may interact with a serum component present on the column that does not react well under our standard Western blot conditions. The extract of JM90 (pTE3), yielding the $59-\mathrm{kD}$ protein but not NodD, served as a useful control, because it failed to interact with any of the DNA fragments containing sequences immediately upstream of nod genes (Fig. 3, panels A-C, lanes 2).

The substantially purified NodDl preparation was tested for its ability to interact with inducible nod-gene promoter fragments. All three inducible promoter fragments, containing DNA sequences immediately upstream of $\operatorname{nodA}$, nodF, and nodH, showed altered mobility in the presence of the NodDl protein fraction (Fig. 5, panels A-C, lanes 3). In addition, this NodD1 preparation failed to interact with three nonspecific control restriction fragments, as shown by a lack of electrophoretic retardation (Fig. 5, panel D, lane 3; and data not shown). A parallel purification using an extract from strain JM90 (pTE3), which is mutated for all three nodD genes, produced a preparation that only contains the

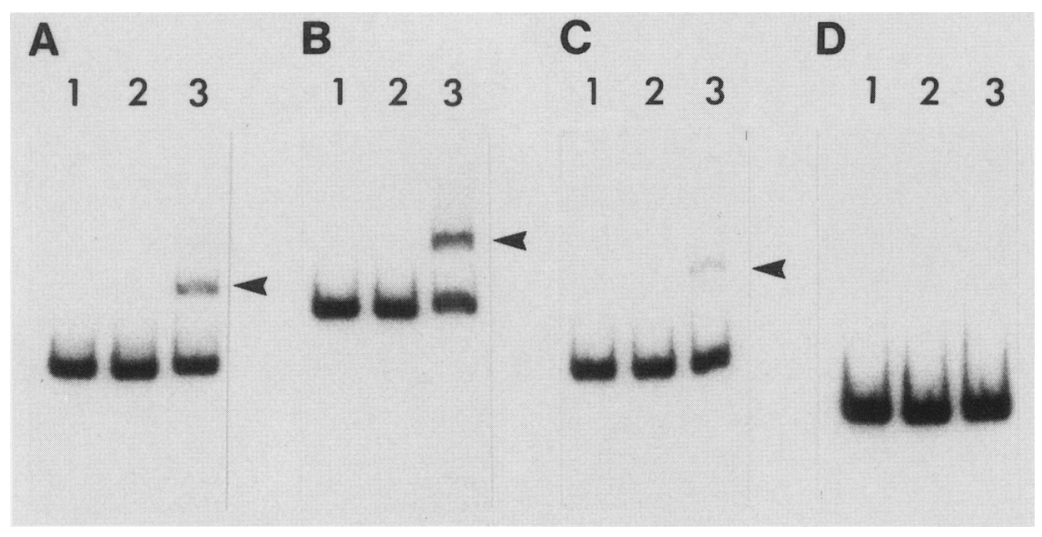

Figure 5. Immunoaffinity-purified NodD1 is able to retard the electrophoretic migration of nod box-containing restriction fragments. (A) The 0.36-kb ${ }^{32} \mathrm{P}-$ labeled pRmE36 BgIII-BamHI restriction fragment, containing DNA sequences upstream of nodA, including the nod box (Fig. 2), was mixed under the conditions of the standard gel retardation assay, as described in Materials and methods, with $0.5 \mu \mathrm{g}$ of immunoaffinity-purified material from: lane 2, R. meliloti strain JM90 (pTE3), which is mutated for all three nodD genes; lane 3, R. meliloti strain 1021 (pRmE43), which overproduces NodDl. Lane 1 displays the electrophoretic migration pattern of the labeled fragment in the absence of any immunoaffinity-purified material. The arrowhead designates the electrophoretically retarded complex. Fig. 4 displays the protein profiles of the two immunoaffinity-purified preparations. $(B)$ Same as in $A$, except that the 0.6-kb pRmRF58 EcoRI- to XmaIII-labeled restriction fragment, containing nodF upstream DNA and the nod box, was used (see Fig. 2). (C) Same as in $A$, except that the 0.35-kb pRmRF59 EcoRI- to PvuII-labeled restriction fragment, containing nodH upstream DNA and the nod box, was used (see Fig. 2). (D) Same as in A, except that the 0.24-kb pRmE36 BglII- to BamHI (Fig. 2) labeled restriction fragment, containing sequences wholly internal to nodD1, was used. 
59-kD protein. This preparation failed to alter the mobility of either the promoter fragments (Fig. 5, panels A-C, lanes 2) or the nonspecific control fragments (Fig. 5 , panel $\mathrm{D}$, lane 2 ; and data not shown).

A double-stranded DNA oligomer homologous to the most conserved portion of the nod box competes for formation of retarded complexes

We chemically synthesized two complementary oligodeoxynucleotides, shown in Figure 6, which are perfectly homologous to the $\operatorname{nodA}$-proximal half of the nod boxes that have been described upstream of nodA for several species (Debelle and Sharma 1986; Rostas et al. 1986; Schofield and Watson 1986; Scott 1986; Shearman et al. 1986|. We annealed these complementary oligomers and used them as competitors in gel retardation experiments, as shown in Figure 7. In panel A, we used the nodA nod box fragment, and in panel $\mathrm{B}$ we used the nodH nod box fragment (see Fig. 2). As in all other gel shift assays, excess nonspecific competitor DNA was present in all lanes, so that any effects of the nod box oligomer should be specific to its sequence. Lane 1 of each panel shows the migration of the fragments in the absence of any added exogenous protein; lane 2 shows the effect of mixing the fragments with extracts from a strain that overproduces NodD3. Clearly, the electrophoretic migration of a substantial portion of each fragment is retarded. Lanes 3 show the effect of adding the annealed oligonucleotides to the mixture prior to the addition of the NodD3 extract. Most of the retarded complexes seen in lanes 2 are no longer observed. Lanes 4 show the effect of mixing the fragments with NodDl purified using the immunoaffinity column described in the previous section. As in lanes 2, electrophoretic retardation of a substantial portion of each fragment occurs. Lanes 5 once again show the effect of the addition of the competing annealed oligonucleotides, with concomitant loss of formation of the retarded complexes. Thus, the addition of short annealed oligonucleotides that are complementary to only a very small portion of these restriction fragments has a very large effect on the ability to form the specifically retarded complexes. These results provide strong evidence arguing for the interaction of NodD with at least part of the nod box. It is also possible that the other conserved sections of the nod box are involved in a NodDDNA interaction.

\section{Discussion}

Control of prokaryotic transcription initiation can display positive, negative, or combined strategies of regulation (Raibaud and Schwartz 1984). This regulation occurs through the interaction of cis DNA sequences, typically upstream of the transcription initiation site, and trans-acting proteins, including RNA polymerase itself and other proteins that affect the ability of RNA polymerase to initiate transcription (Reznikoff et al. 1985 ).

Studies of protein-DNA interactions in E. coli and other systems have indicated that RNA polymerase recognizes sequences centered about 10 and $35 \mathrm{bp}$ upstream of the transcription start site. In strong constitutive promoters for RNA polymerase containing Sigma 70, these sequences approach a characteristic or consensus sequence $5^{\prime}$-TTGACA-3' at $-35 \mathrm{bp}$ and $5^{\prime}$-TATAAT- $3^{\prime}$ at -10 bp (reviewed by McClure 1985; Reznikoff et al. 1985). Promoter mutations decreasing the similarity of these regions to the consensus sequences generally decrease the strength of the promoter, but not always.

Positively regulated promoters vary widely in their molecular characteristics. Some have a distinctly different -10 bp sequence, consistent with their recognition by an RNA polymerase that contains an alternate Sigma factor. This has been observed with heat-shockregulated promoters, phage promoters, and others (reviewed by Reznikoff et al. 1985). Other positively controlled promoters utilize the standard Sigma 70 but do not direct high levels of expression unless there is interaction of DNA sequences farther upstream with positive regulatory proteins, as exemplified by the action of the

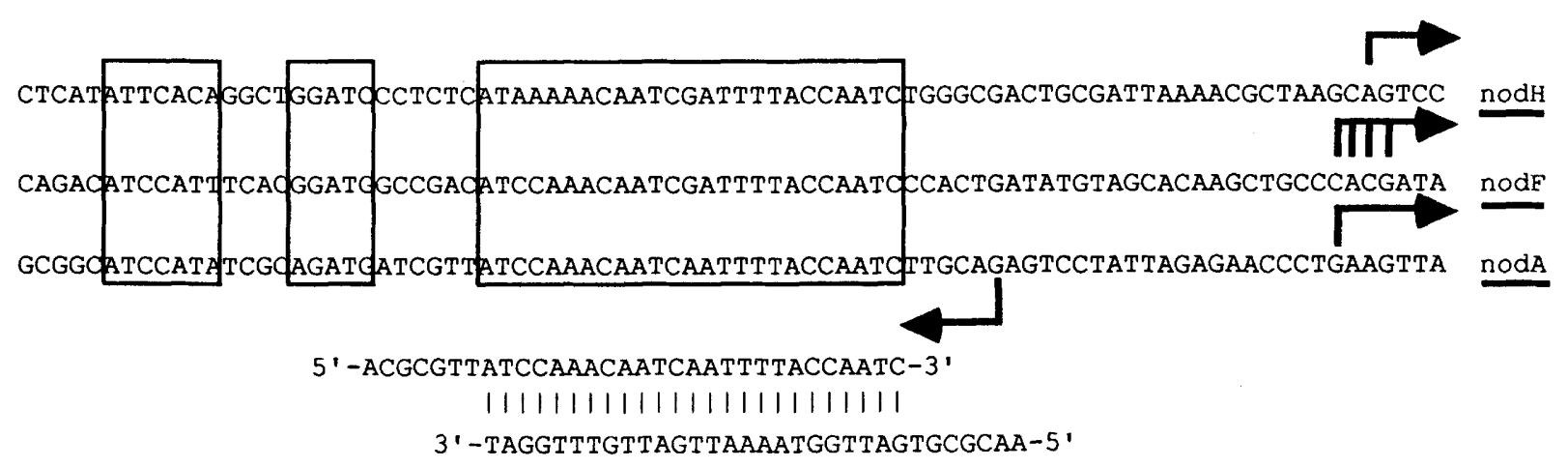

Figure 6. DNA sequences upstream of the inducible nodH, nodFE, and nodABC genes. The nod box sequences described by Rostas et al. (1986) are boxed. In vivo transcription initiation sites for nodH, nodF, and nodA are designated by rightward arrows (Fisher et al. $1987 \mathrm{~b}$; J. Mulligan and S. Long, in prep.). Leftward arrow indicates transcription initiation site of nodD on the opposite strand of the DNA sequence shown (Fisher et al. 1987a). Complementary oligodeoxynucleotides, including a segment with perfect homology to the $\operatorname{nod} A$-proximal half of the nod box, are shown at the bottom. 


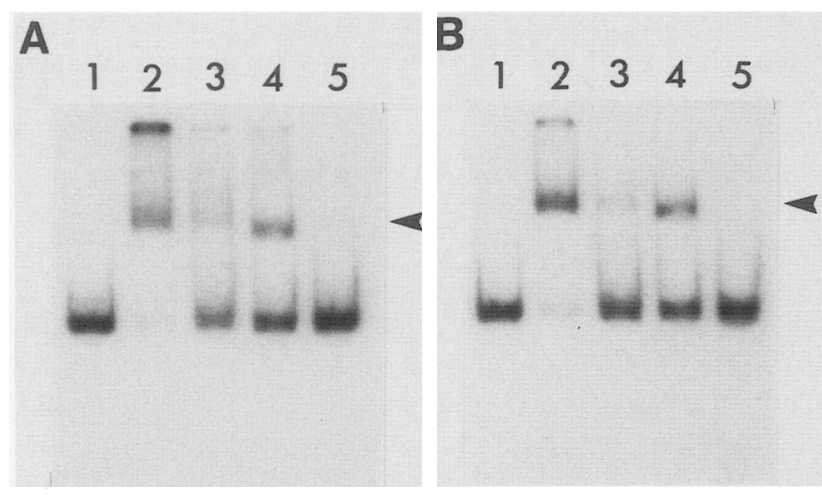

Figure 7. A small double-stranded DNA oligomer homologous to the nod box competes with formation of specific gel-retarded complexes. (A) The 0.36-kb ${ }^{32} \mathrm{P}$-labeled pRmE36 BglII-BamHI restriction fragment containing the segment upstream of nodA, including the nod box (see Fig. 2), was mixed under the conditions of the standard gel retardation assay /see Materials and methods) and run on polyacrylamide gels. (Lane 1) Migration of the labeled restriction fragment in the absence of nodD. (Lanes 2 and 3) Migration of the labeled restriction fragment after addition of $24 \mu \mathrm{g}$ of crude extract from $R$. meliloti strain JM96 (pRmE65), in the absence and presence of $0.8 \mu \mathrm{g}$ of the annealed nod box oligonucleotides (Fig. 6), respectively. The arrowhead designates the electrophoretically retarded complex. (Lanes 4 and 5) Migration of the labeled restriction fragment after addition of $0.5 \mu \mathrm{g}$ of immunoaffinity-purified material in the absence and presence of $0.8 \mu \mathrm{g}$ of the annealed nod box oligonucleotides, respectively. Approximately $10 \%$ of the immunoaffinity-purified material used in this experiment consisted of NodD1; the remainder is the $59-\mathrm{kD}$ protein. The annealed oligonucleotides are shown in Fig. 6. $(B)$ As in panel $A$, except the $0.35-\mathrm{kb}{ }^{32} \mathrm{P}-\mathrm{labeled} E c o \mathrm{RI}-P$ vuII restriction fragment from pRmRF59, containing the nodH nod box (see Fig. 2), was used.

cyclic AMP (cAMP) receptor protein on the lacZYA promoter (deCombrugghe et al. 1984). More complex strategies for promoter control, such as that for the nitrogenregulated genes, also exist. Activation of nitrogen-regulated genes requires both a positive regulatory factor, the $n t r C$-gene product (or in the case of nif operons, the nif $A$ protein), and the specialized Sigma factor, NtrA (reviewed by Gussin et al. 1986). In this system, as in many cases of positive regulation, the exact mechanism by which the upstream DNA and the activating protein cause a change in transcription initiation is unknown.

The formal genetics of nodABC and other nod-gene induction in $R$. meliloti circumstantially predicted positive control: A nod $C^{\prime}-1 a c Z$ fusion was expressed in response to an external signal from the plant host (Mulligan and Long 1985). Induction of this gene fusion was proportional to the copy number of the functional nodD gene, and extra copies of plasmid carrying nod $A B C$ promoter sequences (but with no functional nodD gene) did not enhance expression in such a way as to suggest competition for a repressor (Mulligan and Long 1985). In several systems, the inducibility of nod genes including no$d A B C$, nodFE, and others has been confirmed, as has constitutive expression of nodD (for a broad discussion of this field, see Lugtenberg 1986). Our previous studies have shown, by primer extension analysis, that these three genes are transcriptionally induced by the plant signal molecule, luteolin, in the presence of nodD1; they are highly expressed if extra copies of nodD3 are present (Fisher et al. 1987b; J. Mulligan and S. Long, in prep.). Studies by Rossen et al. (1985) and Shearman et al. (1986) demonstrated the nodD-dependent nature of nod $A B C$ and nodFE induction in $R$. leguminosarum biovar. viciae and further showed a decrease in nod $D^{\prime}$ -'lacZ fusion activity, independent of flavonoid inducer, in strains with high expression of nodD in trans. This negative autoregulatory behavior of $R$. leguminosarum biovar. viciae nodD has not been observed in $R$. meliloti (Mulligan and Long 1985). This difference may be a consequence of the multiple copies of nodD in $R$. meliloti or may reflect differences in the molecular behavior of NodD between the two species.

The results presented in this paper suggest a specific interaction between NodD and the highly conserved DNA sequences upstream of three inducible nod genes. In particular, we found that protein extracts of $R$. meliloti, which overproduce either NodD1 or NodD3, and purified preparations of NodDl, retard the electrophoretic migration of three DNA fragments, which contain sequences immediately upstream of the transcription start sites of $\operatorname{nod} A, \operatorname{nod} F$, and $\operatorname{nod} H$. Using a different approach, J. Burn and A. Johnston have demonstrated that extracts of $R$. leguminosarum biovar. viciae interact with the upstream region of $\operatorname{nod} A$ and $\operatorname{nod} F$ according to the content of normal or mutated copies of the nodD gene (pers. comm.).

There are several potential roles for NodD in the positive regulation of inducible nod-gene expression: It may be a receptor for the plant flavonoid inducer; it may be active in the transduction circuitry between reception and response; or it may act directly as an activator of transcription. A multiple role is also possible. To study the role of the nodD protein, we generated antiserum to a lacZ'-'nodD translational fusion product. This antiserum, which reacts with all three $R$. meliloti nodDgene products and permits them to be distinguished on Western blots, was used to purify substantially the nodD1 protein on an immunoaffinity column.

The eluted protein from this column contained only two major species, NodD1 and a $59-\mathrm{kD}$ protein. This $59-\mathrm{kD}$ protein is present in $R$. meliloti deleted for all three copies of nodD genes and also in $R$. meliloti carrying large deletions of pSym and in Agrobacterium rhizogenes (data not shown). This suggests the possiblity that the $59-\mathrm{kD}$ protein may be the product of a chromosomally located gene; several specific loci and the general chromosome organization are well conserved between Agrobacterium and Rhizobium species (Dylan et al. 1986).

Although it is clear that the electrophoretic retardation of nod box-containing restriction fragments is NodD dependent, at present we are unable to rule out a partial role for the $59-\mathrm{kD}$ polypeptide in the interaction with the nod box. Although the $59-\mathrm{kD}$ polypeptide alone 
fails to casue electrophoretic retardation of the nod box-containing restriction fragments, it is possible that this failure is due to the requirement for NodD to 'activate' the $59-\mathrm{kD}$ protein. Further purification of NodD protein is in progress to permit analysis of the role of NodD alone.

Starting 26-28 bp upstream of the transcription start sites of $\operatorname{nod} A, \operatorname{nodF}$, and nodH is the highly conserved nod box segment; no other DNA homology is notable among these different upstream segments. This suggests that the nod box, the only common DNA segment, is responsible for the altered migration of the fragments. This is further supported by the observation (Fig. 7) that a short duplex oligodeoxynucleotide, including a segment of the nodA nod box, specifically competes with labeled promoter region fragments for interaction with NodD-containing extracts and the purified NodD1 preparation. That this partial nod box oligodeoxynucleotide competes with larger fragments, however, does not rule out a role for the entire nod box or for other promoter sequences in the NodD interaction. Footprinting analysis will be necessary to determine the extent of NodDDNA interaction.

The specific interaction of $R$. meliloti NodD1-rich extracts and of substantially pure NodD1 protein with inducible nod-gene upstream DNA sequences is detectable without plant flavone inducer being present during the growth of the bacterial cultures or during in vitro incubation of protein extracts with DNA fragments. This implies that some level of binding exists in the absence of flavone inducer, but the technique cannot resolve fine differences in the nature of the binding. A low-molecular-weight ligand may alter the DNAbinding specificity of an activator protein or may alter its activity without affecting DNA binding. The cAMP receptor protein binds DNA nonspecifically in the absence of CAMP, but in the presence of CAMP it binds to specific sites near the RNA polymerase binding site of regulated promoters (deCrombrugghe et al. 1984). The araC-gene product (AraC) binds the same specific sites in vivo in the presence of the inducing molecule, L-arabinose, in its absence, or in the presence of the antiinducer, D-fucose (Martin et al. 1986). The lack of a dependence on flavone for the specific DNA binding by the $R$. meliloti extracts suggests that, like AraC, NodD1 binds in the presence or absence of the inducing molecule. Although AraC binds the same sites whether it is inducing or repressing transcription of the araBAD operon, its affinity for the sites is different under the two conditions (Hendrickson and Schleif 1984) and its interaction with RNA polymerase is presumably different. The same may be true for NodD1. Our genetic analysis suggests that some of the nodD-gene products can act both as repressors and activators of nod-gene expression (J. Mulligan and S. Long, in prep.).

Both genetic and detailed biochemical study will be required to analyze promoter affinity, position of binding, interaction with RNA polymerase and/or additional regulatory factors such as inducers, and the protein domains responsible for the various preperties of
NodD. Such analyses will be required to establish whether NodD, RNA polymerase, and/or other proteins interact directly with the nod box or whether other DNA sequences are involved.

\section{Materials and methods}

Strains

Strains and plasmids are listed in Table 1.

\section{Construction of nodD mutants}

Derivatives of $R$. meliloti 1021 with insertions in each pair of nodD genes were constructed as follows. A trimethoprim-resistance plasmid that is incompatible with pLAFR3, pR751, was conjugated into R. meliloti TJ9B8 carrying pRmM139, and the conjugation mixture was selected for neomycin resistance (the Tn5 in nodD1), spectinomycin resistance (the insertion in nodD2), and trimethoprim resistance and screened for tetracycline sensitivity (loss of the plasmid copy of nodD2) to yield $R$. meliloti JM98. The same selection was used on $R$. meliloti JT303 carrying pRmM139 to isolate a strain with the spectinomycin-resistance insertion in $\operatorname{nodD} 2$ and a $\operatorname{Tn} 5$ in $\operatorname{nodD} 3$, giving rise to $R$. meliloti JM97; and on R. meliloti JM61 carrying pRmS303 to isolate a strain with spectinomycin resistance in nodD1 and a Tn5 insertion in nodD3, generating $R$. meliloti JM80. JM90 was constructed by N3 transduction of the linked markers nodD1'-'lacZ and nodD3 :: Tn5 into JM139 (nodD2-uidA), followed by screening for genetic markers and physical genome analysis. JM96 was constructed by N3 transduction of the linked markers nodD1'-'lacZ and syrM :: Tn5 (from JM86) into JM139 (nodD2-uidA), followed by screening for genetic markers and physical genome analysis. Strains that overexpress one of the nodD genes in the absence of the others were constructed by conjugating $\mathrm{pRmM} 137$ into $R$. meliloti JM80, pRmJ30 into $R$. meliloti JM97, and pRmM108 into $R$. meliloti JM98.

\section{Plasmid constructions}

pRmE49, a ColE1-based plasmid in which the nodD structural gene is expressed downstream of the Salmonella typhimurium trp promoter, has only $55 \mathrm{bp}$ of nod DNA between the vector trp promoter and the nodD start codon. Its construction is as follows: pRmE39 (Egelhoff and Long 1985) was digested with HinfI, filled in to blunt ends with Klenow fragment, and ligated to PstI linkers. This material was then digested with PstI to cleave the linkers and EcoRI to cleave the unique restriction site downstream of nodD. The 1030-bp fragment containing nodD and $55 \mathrm{bp}$ of upstream sequence was then cloned as a PstI-EcoRI fragment into the expression vector pADl0 (Egelhoff and Long 1985).

pRmE43, which contains nodD expressed from the $S$. typhimurium trp promoter on a broad host-range vector, was constructed as follows. pRmE36 (Egelhoff and Long 1985) was digested with $P_{s t} \mathrm{I}$ and $B c I I$, and the resulting 1.3 -kb fragment containing the nodD-coding sequence was ligated into pTE3 (Egelhoff and Long 1985), which had been digested with PstI and $\mathrm{BamHI}$.

pRmE53 expresses a lacZ'-'nodD fusion protein that has the first six amino acids of nodD replaced by the first six amino acids of lacZ. This was constructed by cloning a PstI-BamHI fragment from pSKS104 (Shapira et al. 1983) into pRmE39 (Egelhoff and Long 1985), which had been digested with PstI and $B g I I I$. 
Fisher et al.

Table 1. Strains and plasmids

\begin{tabular}{|c|c|c|}
\hline Strain or plasmid & Relevant characteristics or genotype & Source or reference \\
\hline \multicolumn{3}{|l|}{ E. coli } \\
\hline SVS3202 & W3110 (lac-argF)U169 recA1 tnaA2 & V. Stewart \\
\hline \multicolumn{3}{|c|}{ 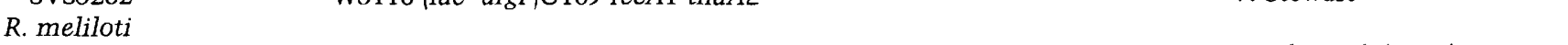 } \\
\hline 1021 & $\mathrm{Str}^{\mathrm{R}}$ derivative of SU47 & Meade et al. (1982) \\
\hline IM80 & $1021, \operatorname{nod} D 11^{\prime}-1 a c Z$, nodD3::Tn5 & this study \\
\hline JM90 & $1021, \operatorname{nodD} 11^{\prime} l a c Z, \operatorname{nodD2}-u i d A, \operatorname{nodD} 3:: \operatorname{Tn} 5$ & this study \\
\hline JM96 & 1021, nodD1'-lacZ, nodD2-uidA, syrM::Tn5 & Mulligan and Long (in prep.) \\
\hline JM97 & $1021, \operatorname{nodD} 3:: \operatorname{Tn} 5, \operatorname{nod} D 2-u i d A$ & this study \\
\hline JM98 & $1021, \operatorname{nodD} 1:: \operatorname{Tn} 5, \operatorname{nodD} 2-u i d A$ & this study \\
\hline Т)9B8 & $1021, \operatorname{nodD} 1:: \operatorname{Tn} 5$ & Jacobs et al. (1985) \\
\hline JT303 & $1021, \operatorname{nodD} 3:: \operatorname{Tn} 5$ & Swanson et al. (1987) \\
\hline JM61 & 1021, nodD1'-'lacz & Mulligan and Long (1985) \\
\hline SL44 & $1021, \Delta(\operatorname{nod} D A B C)$ & this study \\
\hline GMI255 & Nod $^{-} \Delta\left(f_{i x-1074}\right.$ nod nifHDK)7125(Tn5), Nal ${ }^{R}$ & Truchet et al. (1985) \\
\hline $\mathrm{Rm} 41$ & $\mathrm{Nod}^{+}, \mathrm{Fix}^{+}$, wild type & Banfalvi et al. (1981) \\
\hline $\mathrm{Rm} 1400$ & spontaneous deletion derivative of $\mathrm{Rm} 41$ & F.M. Ausubel \\
\hline \multicolumn{3}{|c|}{ Recombinant plasmids } \\
\hline $\mathrm{pRmE} 36$ & ColE1, trp promoter, nodD protein & Egelhoff and Long (1985) \\
\hline pRmE39 & ColE1, trp promoter, nodD protein & Egelhoff and Long (1985) \\
\hline pRmE49 & ColEl, trp promoter, nodD protein & this study \\
\hline pRmE53 & ColEl, trp promoter, $l a c Z^{\prime}-{ }^{\prime}$ nodD fusion protein & this study \\
\hline pTE3 & incP, pLAFR 1 containing polylinker and trp promoter & Egelhoff and Long (1985) \\
\hline pRmE43 & incP, nodD1 expressed under control of $\operatorname{trp}$ promoter in pTE3 & this study \\
\hline pRmE65 & incP, nodD 3 expressed under control of $\operatorname{trp}$ promoter in pTE3 & this study \\
\hline $\mathrm{pRm} / 30$ & incP, 8.7-kb EcoRI fragment, including $R$. meliloti nodD 1 gene & Jacobs et al. (1985) \\
\hline pRm/T5 & incP, $20-\mathrm{kb}$ cosmid bearing nodD3 & Swanson et al. (1987) \\
\hline $\mathrm{pRmS303}$ & pRmJT5 with nodD3::Tn5 insertion & Swanson et al. (1987) \\
\hline pRmM108 & $\begin{array}{l}\text { incP, } 15-\mathrm{kb} \text { deletion product of pRmJT5 containing } R \text {. meliloti nodD3 } \\
\text { gene }\end{array}$ & this study \\
\hline $\mathrm{pRmM137}$ & incP, 6.8-kb fragment, including $R$. meliloti nodD2 gene & this study \\
\hline pRmM139 & incP, nodD2-uidA & this study \\
\hline pUCD2001 & vector based on Agrobacterium tumefaciens plasmid & Gallie et al. (1985) \\
\hline
\end{tabular}

pRmE65 expresses the nodD3 gene from the trp promoter of the broad host-range expression vector pTE3. A 2.2-kb ClaI fragment from pRmJT5 (Fisher et al. 1987b), which spans the nodD3 gene (Mulligan 1987), was cloned into AccI-cut pUC119 to generate $\mathrm{pRmM147}$. A 1.6-kb PstI-BglII restriction fragment from pRmMl47 (the PstI site is in the vector polylinker, and the BglII site is downstream of nodD3/ was ligated into PstI- to BamHI-digested pTE3 to create pRmE65.

pRmF58 and pRmF59 are exonuclease III-digested derivatives of pRmS24 and pRmS23, respectively (Fisher et al. 1987b). pRmF58 was used as a source of a $0.6-\mathrm{kb}$ EcoRI-XmaIII fragment, which contains the $5^{\prime}$ end of nodF and its upstream regulatory region, including the nod box, and also of a $0.45 \mathrm{~kb}$ HindIII-XmaIII fragment, which encodes the $3^{\prime}$ end of nodF and the $5^{\prime}$ end of nodE. pRmF59 was used as a source of a $0.35-\mathrm{kb}$ EcoRI-PvuII fragment that contains the sequences $5^{\prime}$ of nodH, including the nod box, and also of a 0.18-kb EcoRI-PvaII fragment from pUC118. This $0.18-\mathrm{kb}$ fragment contains the pUC118 lac promoter.

\section{Cloning of nodD2 and nodD3}

DNA from $R$. meliloti 1021 was used to construct a Sau3A partial cosmid library in the SalI site of pUCD2001 (Gallie et al. 1985 ) by the protocol of Zabarovsky and Allikmets (1986). Colony hybridization on nylon filters, using as a hybridization probe the $0.6-\mathrm{kb} S s t \mathrm{I}-\mathrm{BamHI}$ fragment that contains the $\operatorname{nod} A B C-\operatorname{nod} D$ intergenic region and part of nodD (Fig. 2) identified 32 recombinant clones with nodD homology. A 6.8- kb EcoRI fragment was subcloned from one of these into the EcoRI site of pBR322, and its restriction map was shown to match that of the nodD2 fragment (Honma and Ausubel 1987). The subcloned fragment was cloned into the EcoRI site of pLAFR3 (B. Staskawicz and D. Dahlbeck, in prep.) to form pRmM137. An insertion into nodD2 was generated by cloning a 4-kb HindIII fragment carrying spectinomycin resistance and a promoterless glucuronidase (uidA) gene into the $\mathrm{XbaI}$ site in pRmJM137 to form pRmJM139 (Jefferson et al. 1986). A nodD3 clone was generated by XhoI digestion of pRmJT5, followed by religation at low DNA concentration to form $\mathrm{pRmM} 108$.

\section{Fusion protein isolation}

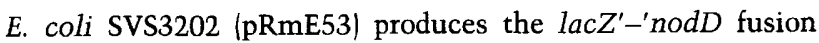
protein at high level, and the majority of the protein is in the form of insoluble inclusion bodies (Egelhoff 1987). This strain was grown in LB medium supplemented with ampicillin to near saturation. Cells were harvested by centrifugation, resuspended in $50 \mathrm{~mm}$ Tris, $\mathrm{pH} 8.0$, and broken by passage through a French pressure cell twice at 14,000 psi. Inclusion bodies containing the fusion protein were pelleted by centrifugation at $3000 \mathrm{~g}$ for $15 \mathrm{~min}$. At this stage, the nodD protein is approximately $70 \%$ pure, as determined by SDS-polyacrylamide gel electrophoresis. The inclusion bodies were solubilized by boiling in gel sample buffer $(5 \%$ Tris base, $5 \%$ SDS, $10 \% 2$ mercaptoethanol, and $0.01 \%$ bromphenol blue) and loaded directly onto preparative SDS-polyacrylamide gels. Following electrophoresis, gels were stained briefly, and the NodD fusion 
protein was excised and electroeluted as described previously (Egelhoff and Long 1985).

\section{Generation of antibodies}

Electroeluted protein was precipitated with trichloroacetic acid, resuspended in $\mathrm{H}_{2} \mathrm{O}$, and reprecipitated with acetone. Then, $250 \mu \mathrm{g}$ of this material was emulsified in incomplete Freund's adjuvant and injected subcutaneously into a New Zealand white rabbit. The rabbit was boosted at 5-week intervals with $200 \mu \mathrm{g}$ additional purified protein by the same method. Blood was collected via ear bleeds 7-10 days after boosts. Serum was processed by standard methods (Hurn and Chantler 1980). Western blots were conducted as described previously (Egelhoff and Long 1985).

\section{Immunoadsorption of extracts}

Protein A-Sepharose (Pharmacia) was hydrated in $50 \mathrm{~mm}$ Tris (pH 7.5), and $20-\mu \mathrm{l}$ settled volume was mixed gently at $4^{\circ} \mathrm{C}$ for 5 hr with $100 \mu \mathrm{l}$ of anti-NodD serum or preimmune serum from the same rabbit. The resin was washed four times with $0.4 \mathrm{ml}$ of the same buffer and mixed with $100 \mu \mathrm{l}$ of a $R$. meliloti 1021 (pRmE43) protein extract for $2 \mathrm{hr}$ at $4^{\circ} \mathrm{C}$. The mixture was centrifuged to remove the Sepharose, and the treated extracts were transferred to fresh tubes.

\section{Preparation of cell extracts}

Strains were grown in TY under appropriate antibiotic selection with shaking at $30^{\circ} \mathrm{C}$. Cells were harvested by centrifugation, washed in T-2ME (25 mM Tris- $\mathrm{HCl}$ at $\mathrm{pH} 8.0,5 \mathrm{~mm}$ 2-mercaptoethanol), and resuspended in $2-3 \mathrm{ml} \mathrm{T}-2 \mathrm{ME}$ containing 8 $\mu \mathrm{g} / \mathrm{ml}$ leupeptin, $2 \mu \mathrm{g} / \mathrm{ml}$ chymostatin, $10 \mu \mathrm{g} / \mathrm{ml}$ pepstatin, and I $\mathrm{mm}$ phenylmethylsulfonylfluoride. The cells were then passed twice through a French pressure cell at 15,000 psi. The lysed mixture was clarified by centrifugation at $4000 \mathrm{~g}$ for 10 min at $4^{\circ} \mathrm{C}$. The supernatant fluid was removed and subjected to centrifugation at $100,000 \mathrm{~g}$ for $2 \mathrm{hr}$ at $4^{\circ} \mathrm{C}$ to remove membranes. The fluid was then removed and stored at $-70^{\circ} \mathrm{C}$ as aliquots to be used in the shift gel assays. Protein concentration of the extracts was determined by a method based on the Bradford (1976) dye-binding procedure, using the BioRad protein assay. The undiluted extracts ranged from 5 to $25 \mathrm{mg} / \mathrm{ml}$.

\section{Gel electrophoresis-DNA-binding assay}

Binding of extract proteins to DNA was monitored by the reduction of the electrophoretic mobility of labeled DNA fragments, as described by Fried and Crothers (1981), with the modification of Miller et al. (1987). The standard protocol was as described, except that $1 \mu \mathrm{g}$ unlabeled sonicated pBR322 DNA was added as competitor. Restriction fragments $(\sim 2 \mathrm{ng})$, end-labeled as described by Maniatis et al. (1982), were incubated with soluble extracts at $23^{\circ} \mathrm{C}$ for $20 \mathrm{~min}$ in binding buffer [ 10 $\mathrm{mM}$ Tris- $\mathrm{Cl}$ at $\mathrm{pH} 7.5,1 \mathrm{~mm}$ EDTA, $100 \mathrm{~mm} \mathrm{KCl}, 0.1 \mathrm{~mm}$ dithiothreitol (DTT) $5 \%$ glycerol, and $50 \mu \mathrm{g} / \mathrm{ml}$ bovine serum albumin (BSA)] in a final volume of $10 \mu \mathrm{l}$. Loading buffer $(3 \mu \mathrm{l})$ consisting of binding buffer plus $20 \%$ glycerol and $1 \mu \mathrm{g} / \mathrm{ml}$ bromphenol blue and xylene cyanol-FF was added to the samples, which were then subjected to electrophoresis on 0.75 $\mathrm{mm}$ thick $5 \%$ TBE (Tris-borate-EDTA)-polyacrylamide slab gels at $150 \mathrm{~V}$ and $4^{\circ} \mathrm{C}$. Gels were prerun under these conditions for at least $1 \mathrm{hr}$ prior to sample application. The gels were dried and the migration of DNA fragments was visualized by autoradiography.
Preparation of oligodeoxynucleotides homologous to the nod box

Two complementary oligodeoxynucleotides, 5'-ACGCGTTATCCAAACAATCAATTTTACCAATC- ${ }^{\prime}{ }^{\prime}$ and $5^{\prime}$ AACGCGTGATTGGTAAAATTGATTGTTTGGAT-3', were synthesized by standard phosphoramidite chemistry (McBride and Caruthers 1983) on an Applied Biosystems model 380B DNA synthesizer. These 32 -mers include 25 bp perfectly homologous to the most extensively conserved portion of the $\operatorname{nod} A$ nod box. The complementary 32 -mers were annealed as described by Kadonaga and Tjian (1986): In $50 \mu \mathrm{l}$ annealing buffer $167 \mathrm{mM}$ Tris- $\mathrm{HCl}$ at $\mathrm{pH} 7.6,13 \mathrm{mM} \mathrm{MgCl}_{2}, 6.7 \mathrm{~mm}$ DTT, $1.3 \mathrm{~mm}$ spermidine, and $1.3 \mathrm{mM}$ EDTA), $10 \mu \mathrm{g}$ of each oligonucleotide was mixed and placed in a $100^{\circ} \mathrm{C}$ heating block, which was immediately switched off and allowed to cool slowly over $1 \mathrm{hr}$ to $35^{\circ} \mathrm{C}$. The annealed oligonucleotides were stored at $-20^{\circ} \mathrm{C}$.

\section{Immunoaffinity column chromatography}

Protein A-Sepharose CL-4B (Pharmacia) was suspended in 0.1 $\mathrm{M}$ borate buffer at $\mathrm{pH} 8.2$. Then, $2.5 \mathrm{ml}$ of settled Sepharose $(\sim 0.3 \mathrm{~g})$ was mixed with $27 \mathrm{mg}$ antibody generated to the lacZ'-'nodD hybrid protein in $0.1 \mathrm{M}$ borate buffer at $\mathrm{pH} 8.2$ in a total volume of $10 \mathrm{ml}$. This was shaken gently for $30 \mathrm{~min}$ at room temperature, washed once with borate buffer and three times with $0.2 \mathrm{M}$ triethanolamine at $\mathrm{pH}$ 8.2. The immunoaffinity beads were then suspended in $40 \mathrm{ml}$ of freshly made 50 $\mathrm{mM}$ dimethyl pimelimidate dihydrochloride in $0.2 \mathrm{M}$ triethanolamine at $\mathrm{pH} 8.2$. The mixture was agitated gently at room temperature for $45 \mathrm{~min}$, and the reaction was stopped by centrifuging the beads at $500 \mathrm{~g}$ for $5 \mathrm{~min}$ and resuspending in an equal volume of $50 \mathrm{~mm}$ ethanolamine at $\mathrm{pH} 8.2$. After $5 \mathrm{~min}$, the beads were washed twice with $0.1 \mathrm{M}$ borate buffer at $\mathrm{pH} 8.2$, twice with $50 \mathrm{mM}$ triethylamine at $\mathrm{pH} 11.5$, and then immediately with three washes of $0.1 \mathrm{M}$ borate buffer at $\mathrm{pH} 8.2$. Immunoaffinity beads were stored in $0.1 \mathrm{M}$ borate buffer at $\mathrm{pH} 8.2$, with $0.1 \%$ sodium azide at $4^{\circ} \mathrm{C}$. When the beads were packed into columns, they were also stored under the same conditions.

Extracts for purification of NodD1 were generally made from 1 to 2 liters of late log phase cells grown in selective TY media. All steps were performed at $0-4^{\circ} \mathrm{C}$. Cells were harvested, washed with $50 \mathrm{~mm}$ Tris at $\mathrm{pH} 7.5$ and $5 \mathrm{~mm} 2$-mercaptoethanol, and resuspended in $10 \mathrm{ml}$ of the same buffer per liter of original culture. Cells were lysed by three passages through a French press at 14,000 psi. Immediately after lysis, protease inhibitors were added to a final concentration of $1 \mathrm{~mm}$ phenylmethylsulfonylfluoride, $8 \mu \mathrm{g} / \mathrm{ml}$ leupeptin, $2 \mu \mathrm{g} / \mathrm{ml}$ chymostatin, and 10 $\mu \mathrm{g} / \mathrm{ml}$ pepstatin. The extract was centrifuged at $100,000 \mathrm{~g}$ for 1 $\mathrm{hr}$; the supernatant was treated with protamine sulfate 10.67 $\mathrm{mg} / 1000 \mathrm{~A}_{600}$ units original culture) for $5 \mathrm{~min}$, and centrifuged at $8000 \mathrm{~g}$ for $10 \mathrm{~min}$. The supernatant was then applied to the immunoaffinity column.

A $1-\mathrm{ml}$ immunoaffinity column was equilibrated with $50 \mathrm{~mm}$ Tris at $\mathrm{pH} 8$, and the extract was loaded at $10 \mathrm{ml} / \mathrm{hr}$. The column was then washed with $5 \mathrm{ml}$ each of equilibration buffer, equilibration buffer containing $0.5 \mathrm{M} \mathrm{NaCl}$, and equilibration buffer containing $0.1 \%$ NP-40. Protein bound to the column was eluted with $50 \mathrm{~mm}$ triethylamine at $\mathrm{pH} 11.5$, containing $0.1 \%$ NP-40. Fractions eluted from the column were immediately neutralized with one-tenth volume $1 \mathrm{M} \mathrm{NaH} \mathrm{NO}_{4}$. Protein concentration of fractions was determined via the BioRad protein assay, using BSA as a standard. Aliquots of column fractions were routinely analyzed by SDS-polyacrylamide gel electrophoresis (Laemmli 1970). 


\section{Acknowledgments}

We thank M.S. DuBow (McGill University) and the members of our research group for useful discussions; Mark Dudley for work on nodD protein immunoblots; A.W.B. Johnston and colleagues for communicating results prior to publication; and C. Yanofsky and R. Simoni for the use of equipment. We are grateful to Jean Swanson and Mark Dudley for strain construction; Mary Honma (Harvard University) for unpublished nodD2 sequence data; and F. Ausubel, A. Kondorosi, J. Denarie and their colleagues for gifts of strains. We thank J. Cooper, N. Federspiel, J. Schwedock, and J. Ogawa for a critical reading of the manuscript; and A. Bloom for her skill in its preparation. This research was supported by National Institutes of Health grant 5-RO1-GM30962 (to S.R.L.). T.T.E. and J.T.M. were supported, in part, by Cell- and Molecular Biology Training Grant GM07276 from the National Institutes of Health to Stanford University.

\section{References}

Appelbaum, E., N. Chartrain, D. Thompson, K. Johansen, M. O'Connell, and T. McLoughlin. 1985. Genes of Rhizobium japonicum involved in development of nodules. In Nitrogen fixation research progress (ed. H.J. Evans, P.J. Bottomley, and W.E. Newton), pp. 101-107.

Banfalvi, Z., V. Sakanyan, C. Koncz, A. Kiss, I. Dusha, and A. Kondorosi. 1981. Localization of nodulation and nitrogen fixation genes on a high molecular weight plasmid of $R$. meliloti. Mol. Gen. Genet. 184: 318-325.

Bradford, M.M. 1976. A rapid and sensitive method for the quantitation of microgram quantities of protein utilizing the principle of protein-dye binding. Anal. Biochem. 72: 248254.

Burn, J., L. Rossen, and A.W.B. Johnston. 1987. Four classes of mutations in the nodD gene of Rhizobium leguminosarum biovar. viciae that affect its ability to autoregulate and/or activate other nod genes in the presence of flavonoid inducers. Genes Dev. 1: 456-464.

Debellé, F. and S.B. Sharma. 1986. Nucleotide sequence of $R$ hizobium meliloti RCR2011 genes involved in host specificity of nodulation. Nucleic Acids Res. 14: 7453-7472.

Debellé, F., C. Rosenberg, J. Vasse, F. Maillet, E. Martinez, J. Dénarié, and G. Truchet. 1986. Assignment of symbiotic developmental phenotypes to common and specific nodulation (nod) genetic loci of Rhizobium meliloti. J. Bacteriol. 168: 1075-1086.

deCrombrugghe, B., S. Busby, and H. Buc. 1984. Activation of transcription by the cyclic AMP receptor protein. Science 224: 831-837.

Diordjevic, M.A., P.R. Schofield, and B.G. Rolfe. 1985a. Tn5 mutagenesis of Rhizobium trifolii host-specific nodulation genes result in mutants with altered host-range ability. Mol. Gen. Genet. 200: 463-471.

Diordjevic, M.A., P.R. Schofield, R.W. Ridge, N.A. Morrison, B.J. Bassam, J. Plazinski, J.M. Watson, and B.G. Rolfe. 1985b. Rhizobium nodulation genes involved in root hair curling (Hac) are functionally conserved. Plant Mol. Biol. 4: 147160.

Dylan, T., L. Ielipi, S. Stanfield, L. Kashyap, C. Douglas, M. Yanofsky, E. Nester, D.R. Helinski, and G. Ditta. 1986. Rhizobium meliloti genes required for nodule development are related to chromosomal virulence genes in Agrobacterium tumefaciens. Proc. Natl. Acad. Sci. 83: 4403-4407.

Egelhoff, T.T. 1987. "Molecular analysis of Rhizobium meliloti nodulation genes and gene products." Ph.D. dissertation, Stanford University, Stanford, California.
Egelhoff, T.T. and S.R. Long. 1985. Rhizobium meliloti nodulation genes: Identification of nodABC gene products, purification of nodA protein, and expression of nodA in Rhizobium meliloti. J. Bacteriol. 164: 591-599.

Egelhoff, T.T., R.F. Fisher, T.W.Jacobs, J.T. Mulligan, and S.R. Long. 1985. Nucleotide sequence of Rhizobium meliloti 1021 nodulation genes: nodD is read divergently from nodABC. DNA 4: 241-248.

Evans, I.J. and J.A. Downie. 1986. The nodI gene product of Rhizobium leguminosarum is closely related to the ATPbinding bacterial transport proteins: Nucleotide sequence analysis of the nodI and nodI genes. Gene 43: 95-102.

Firmin, J.L., K.E. Wilson, L. Rossen, and A.W.B. Johnston. 1986. Flavonoid activation of nodulation genes in Rhizobium reversed by other compounds present in plants. Nature 324: 90-92.

Fisher, R.F., J.K. Tu, and S.R. Long. 1985. Conserved nodulation genes in Rhizobium meliloti and Rhizobium trifolii. Appl. Environ. Microbiol. 49: 1432-1435.

Fisher, R.F., H.L. Brierley, J.T. Mulligan, and S.R. Long. 1987a. Transcription of Rhizobium meliloti nodulation genes: Identification of a nodD transcription initiation site in vitro and in vivo. J. Biol. Chem. 262: 6849-6855.

Fisher, R.F., J. Swanson, J.T. Mulligan, and S.R. Long. 1987b. Extended nodulation gene region in Rhizobium meliloti 1021. II. Sequence, protein products, and transcription start sites for nod FEGH. Genetics 117: 191-201.

Fried, M. and D.M. Crothers. 1981. Equilibria and kinetics of lac repressor-operator interactions by polyacrylamide gel electrophoresis. Nucleic Acids Res. 9: 6505-6525.

Gallie, D.R., S. Novak, and C.I. Kado. 1985. Novel high and low-copy stable cosmids for use in Agrobacterium and Rhizobium. Plasmid 14: 171-175.

Göttfert, M., B. Horvath, E. Kondorosi, P. Putnoky, F. Rodriguez-Quinones, and A. Kondorosi. 1986. At least two nodD genes are necessary for efficient nodulation of alfalfa by $R$ hizobium meliloti. I. Mol. Biol. 191: 411-420.

Gussin, G.N., C.W. Ronson, and F.M. Ausubel. 1986. Regulation of nitrogen fixation genes. Annu. Rev. Genet. 20: $567-$ 591.

Hendrickson, W. and R.F. Schleif. 1984. Regulation of the Escherichia coli L-arabinose operon studied by gel electrophoresis DNA binding assay. I. Mol. Biol. 174: 611-628.

Honma, M.A. and F.M. Ausubel. 1987. Rhizobium meliloti has three functional copies of the nodD symbiotic regulatory gene. Proc. Natl. Acad. Sci. 84: 8558-8562.

Horvath, B., C.W.B. Bachem, J. Schell, and A. Kondorosi. 1987. Host-specific regulation of nodulation genes in Rhizobium is mediated by a plant-signal interacting with the nodD gene product. EMBO I. 6: 841-848.

Horvath, B., E. Kondorosi, M. John, J. Schmidt, I. Torok, L.Z. Gyorgypa, I. Barabas, U. Wieneke, J. Schell, and A. Kondorosi. 1986. Organization, structure and symbiotic function of Rhizobium-meliloti nodulation genes determining host specificity for alfalfa. Cell 46: 335-344.

Hurn, B.A.L. and S.M. Chantler. 1980. Production of reagent antibodies. Methods Enzymol. 70: 104-142.

Innes, R.W., P.L. Kuempel, J. Plazinski, H. Canter-Cremers, B.G. Rolfe, and M.A. Djordjevic. 1985. Plant factors induce expression of nodulation and host-range genes in Rhizobium trifolii. Mol. Gen. Genet. 201: 426-432.

Jacobs, T.W., T.T. Egelhoff, and S.R. Long. 1985. Physical and genetic map of a Rhizobium meliloti nodulation gene region and nucleotide sequence of nodC. $J$. Bacteriol. 162: 469476.

Jefferson, R.A., S.M. Burgess, and D. Hirsch. 1986. Beta-gluc- 
uronidase from E. coli as a gene fusion marker. Proc. Natl. Acad. Sci. 83: 8447-8451.

Kadonaga, J.T. and R. Tjian. 1986. Affinity purification of sequence-specific DNA binding proteins. Proc. Natl. Acad. Sci. 83: 5889-5893.

Laemmli, U.K. 1970. Cleavage of structural proteins during the assembly of the head of bacteriophage T4. Nature 227: 680685.

Long, S.R. 1986. Genetic advances in the study of Rhizobium nodulation. In Genetic engineering--Principles and methods (ed. J.K. Setlow and A. Hollaender), pp. 135-150. Plenum Press, New York.

Lugtenberg, B., ed. 1986. Recognition in microbe-plant symbiotic and pathogenic interactions. Springer-Verlag, Berlin, Heidelberg, New York, London, Paris, Tokyo.

Maniatis, T., E.F. Fritsch, and J. Sambrook. 1982. Molecular cloning: A laboratory manual, pp. 545. Cold Spring Harbor Laboratory, Cold Spring Harbor, New York.

Martin, K., L. Huo, and R.F. Schleif. 1986. The DNA loop model for ara repression: AraC protein occupies the proposed loop sites in vivo and repression-negative mutations lie in these same sites. Proc. Natl. Acad. Sci. 83: 36543658.

McBride, L.J. and M.H. Caruthers. 1983. An investigation of several deoxynucleoside phosphoramidites useful for synthesizing deoxypolynucleotides. Tetrahedron Lett. 24: 245248.

McClure, W.R. 1985. Mechanism and control of transcription initiation in prokaryotes. Annu. Rev. Biochem. 54:171204.

Meade, H.M., S.R. Long, G.B. Ruvkun, S.E. Brown, and F.M. Ausubel. 1982. Physical and genetic characterization of symbiotic and auxotrophic mutants of Rhizobium meliloti induced by transposon Tn5 mutagenesis. I. Bacteriol. 149: $114-122$.

Miller, V.L., R.K. Taylor, and J.J. Mekalanos. 1987. Cholera toxin transcriptional activator ToxR is a transmembrane DNA binding protein. Cell 48: 271-279.

Mulligan, J.T. 1987. "Regulation of the Rhizobium meliloti nodulation genes." Ph.D dissertation, Stanford University, Stanford, California.

Mulligan, J.T. and S.R. Long. 1985. Induction of Rhizobium meliloti nodC expression by plant exudate requires nodD. Proc. Natl. Acad. Sci. 82: 6609-6613.

Peters, N.K., J.W. Frost, and S.R. Long. 1986. A plant flavone, luteolin, induces expression of Rhizobium meliloti nodulation genes. Science 233: 917-1008.

Putnoky, P. and A. Kondorosi. 1986. Two gene clusters of Rhizobium meliloti code for early essential nodulation functions and a thrid influences nodulation efficiency. $J$. Bacteriol. 167: 881-887.

Raibaud, O. and M. Schwartz. 1984. Positive control of transcription initiation in bacteria. Annu. Rev. Genet. 18: 173206.

Redmond, J.W., M. Batley, M.A. Djordjevic, R.W. Innes, P.L. Kuempel, and B.G. Rolfe. 1986. Flavones induce expression of nodulation genes in Rhizobium. Nature 323: 632-634.

Reznikoff, W.S., D.A. Siegele, D.W. Cowing, and C.A. Gross. 1985. The regulation of transcription initiation in bacteria. Annu. Rev. Genet. 19: 355-387.

Rossen, L., A.W.B. Johnston, and J.A. Downie. 1984. DNA sequence of the Rhizobium leguminosarum nodulation genes nod $A B$ and $C$ required for root hair curling. Nucleic Acids Res. 12: 9497-9508.

Rossen, L., C.A. Shearman, A.W.B. Johnston, and J.A. Downie. 1985. The nodD gene of Rhizobium leguminosarum is au- toregulatory and in the presence of plant exudate induces the nod $A, B, C$ genes. EMBO J. 4: 3369-3373.

Rostas, K., E. Kondorosi, B. Horvath, A. Simoncsits, and A. Kondorosi. 1986. Conservation of extended promoter regions of nodulation genes in Rhizobium. Proc. Natl. Acad. Sci. 83: $1757-1761$.

Schofield, P.R. and J.M. Watson. 1986. DNA sequence of $R h i-$ zobium trifolii nodulation genes reveals a reiterated and potentially regulatory sequence preceding nod $A B C$ and nodFE. Nucleic Acids Res. 14: 2891-2903.

Scott, K.F. 1986. Conserved nodulation genes from the non-legume symbiont Bradyrhizobium sp. (Parasponia). Nucleic Acids Res. 14: 2905-2919.

Shapira, S.K., J. Chou, F.V. Richaud, and M.J. Casadaban. 1983. New versatile plasmid vectors for expression of hybrid proteins coded by a cloned gene fused to $1 a c Z$ gene sequences encoding an enzymatically active carboxy-terminal portion of Beta-galactosidase. Gene 25: 71-82.

Shearman, C.A., L. Rossen, A.W.B. Johnston, and J.A. Downie. 1986. The Rhizobium leguminosarum nodulation gene nodF encodes a polypeptide similar to acyl-carrier protein and is regulated by nodD plus a factor in pea root exudate. EMBO J. 5: 647-652.

Shine, J. and L. Dalgarno. 1974. The 3' terminal sequence of $E$. coli $15 \mathrm{~S}$ ribosomal RNA: Complementarity to nonsense triplets and ribosomal binding sites. Proc. Natl. Acad. Sci. 71: $1342-1346$.

Spaink, H.P., C.A. Wijffelman, E. Pees, R.J.H. Okker, and B.J.J. Lugtenberg. 1987. Rhizobium nodulation gene nodD as a determinant of host specificity. Nature 328: 337-340.

Swanson, J., J.K. Tu, J.M. Ogawa, R. Sanga, R. Fisher, and S.R. Long. 1987. Extended region of nodulation genes in Rhizobium meliloti 1021 . I. Phenotypes of Tn5 insertion mutants. Genetics 117: 181-189.

Törok, I., E. Kondorosi, T. Stepkowski, J. Posfai, and A. Kondorosi. 1984. Nucleotide sequence of Rhizobium meliloti nodulation genes. Nucleic Acids Res. 12: 9509-9524.

Truchet, G., F. Debellé, J. Vasse, B. Terzaghi, A.-M. Garnerone, C. Rosenberg, J. Batut, F. Maillet, and J. Dénarié. 1985. Identification of a Rhizobium meliloti P-sym-2011 region controlling the host specificity of root hair curling and nodulation. I. Bacteriol. 164: 1200-1210.

Zaat, S.A.J., C.A. Wijffelman, H.P. Spaink, A.A.N. Van Brussel, R.J.H. Okker, and G.J.J. Lugtenberg. 1987. Induction of the nodA promoter of Rhizobium leguminosarum Sym plasmid PRL1JI by plant flavanones and flavones. I. Bacteriol. 169: $198-204$

Zabarovsky, E.R. and R.L. Allikmets. 1986. An improved technique for the efficient construction of gene libraries by partial filling-in of cohesive ends. Gene 42: 119-123. 


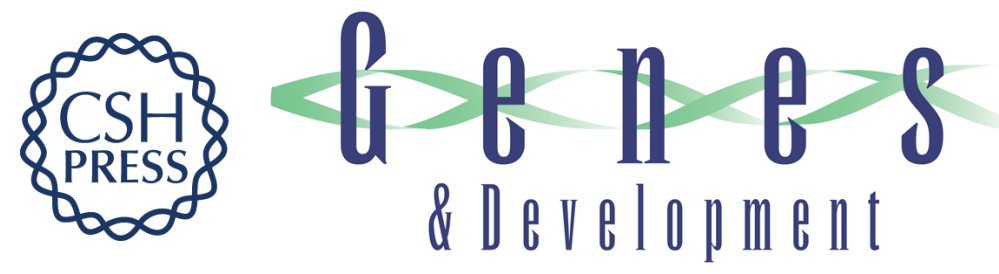

\section{Specific binding of proteins from Rhizobium meliloti cell-free extracts containing NodD to DNA sequences upstream of inducible nodulation genes.}

R F Fisher, T T Egelhoff, J T Mulligan, et al.

Genes Dev. 1988, 2:

Access the most recent version at doi:10.1101/gad.2.3.282

References This article cites 55 articles, 21 of which can be accessed free at:

http://genesdev.cshlp.org/content/2/3/282.full.html\#ref-list-1

License

Email Alerting Receive free email alerts when new articles cite this article - sign up in the box at the top Service right corner of the article or click here.

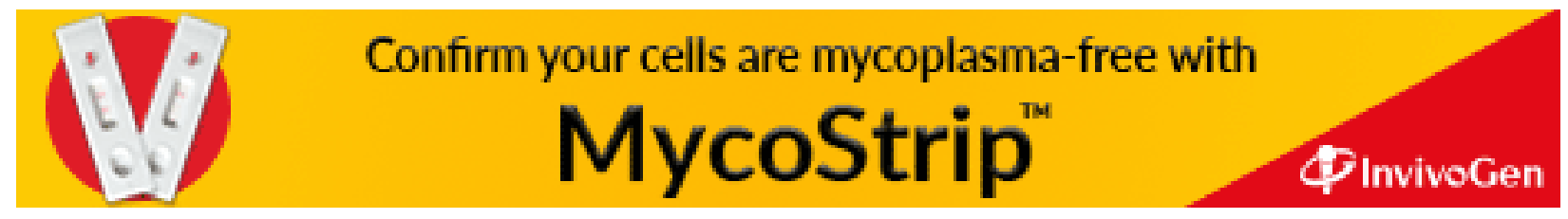

